\title{
As Raízes dos Conflitos entre o Norte e o Sul do Sudão: 0 Processo de Formação do Estado-N ação (1930-1956) $)^{1}$
}

\author{
Frederico Saza deQuinzz Assis
}

\begin{abstract}
Resumo: Este artigo tem como objetivo central identificar as raízes dos conflitos entre o norte e o sul do Sudão, a partir do estudo do processo de formação de seu Estado-nação. A partir do estabelecimento da SathemPdigy (1930) - marco fundamental dentro do projeto mais amplo da administração colonial em distinguir as regiões norte e sul do Sudão -, privilegia-se compreender os aspectos mais relevantes, entre 1930 e 1956, no Sudão, levando-se em conta a formação das identidades coletivas, nem sempre conciliáveis, no bojo do processo de construção do Estado-nação.
\end{abstract}

Palavras-Chave: Sudão, Condomínio Anglo-Egípcio, Nacionalismos, Conflitos Armados

\begin{abstract}
This article aims to identify the roots of the conflicts between north and south of Sudan, from the study of the formation of their nation-state. From the establishment of the Southern Policy (1930) - key landmark within the larger project of the colonial administration to distinguish north and south of Sudan - the focus is on understanding the most relevant issues, between 1930 and 1956, in Sudan taking into account the formation of collective identities, not always reconcilable, in the midst of the nation-state construction.
\end{abstract}

Key-words: Sudan, Anglo-Egyptian Condominium, Nationalisms, Armed Conflicts

\section{1- Introdução}

Este artigo tem como objetivo central identificar as raízes dos conflitos entre 0 norte e o sul do Sudão, a partir do estudo do processo de formação de seu Estado-nação. A partir do estabelecimento da Sauthem Pdig (1930) - marco fundamental dentro do projeto mais amplo da administração colonial em distinguir as regiões norte e sul do Sudão - , privilegia-se compreender os aspectos mais relevantes (porque fundacionais de estruturas históricas ainda persistentes), entre 1930 e 1956 no Sudão, e a influência destes na condução dos rumos para a independência do país. Deste modo, pensando a dinâmica da sociedade colonial, ganham destaque os contextos cosmopolitas onde atuam grupos sociais específicos que, amalgamados em movimentos nacionalistas, discutem a "questão nacional" e a independência sudanesa como partes de um projeto a ser alcançado. Diante desse processo, torna-se possível a compreensão da \$ciedade no Sudão, com as suas especificidades históricas e a complexidade de seu dinamismo cultural, e que não pode ser observada sem se levar em conta a formação das identidades coletivas, nem sempre conciliáveis, no bojo do processo de construção do Estado-nação. Assim, um estudo sistemático desse conjunto de aspectos exige uma releitura do Sudão até sua independência, permitindo compreender a complexa situação de um país assolado por guerras civis.

\footnotetext{
${ }^{1}$ Este artigo é fruto de um trabalho de iniciação científica desenvolvido entre 2007 e 2008, com bolsa da Fundação de Amparo à Pesquisa do Estado de São Paulo (FAPESP). Em especial, agradeço à Profa D ra Leila Leite Hernandez (FFLCH-USP) pela orientação atenciosa em todo o processo.

${ }_{2}^{2}$ Freekico Saza de Quarrz Assis é aluno do 80 período do Bacharelado em Relações Internacionais da Universidade de São Paulo.
} 
O Sudão vem sendo descrito por grande parte da literatura como "microcosmo da África”" ${ }^{3}$. De fato, o maior país do continente africano - e décimo maior do mundo mostra, sob diversos ângulos, capturar uma representação da África dentro de si. A conjunção propícia de elementos confere ao país um caráter singular, na medida em que sua riqueza interna - do ponto de vista físico-geográfico, étnico e lingǘstico - favorece uma configuração sócio-cultural de similitude às diversas faces do continente africano. Do mesmo modo, o Sudão parece aghtinar vários dos dilemas vivenciados pelos povos africanos: o drama da experiência colonial; regimes políticos autoritários; desigualdade social (por vezes, abundância de recursos nas sociedades urbanas, altamente modemizadas, em contraste com a paupenização de zonas rurais); expropriação de recursos naturais pelas elites nacionais ou por países do eixo central do sistema internacional; e conflitos armados que devastam o país por décadas".

Situado no norte do continente, o país faz fronteira com nove países (Chade, Egito, Eritréia, Etiópia, Líbia, Quênia, República Centro-Africana, República Democrática do Congo e Uganda), além de ter saída para o mar Vermelho (o que o aproxima da Arábia Saudita). No norte do Sudão, o aspecto desértico toma conta da paisagem, enquanto no sul savanas e florestas tropicais desenham 0 cenário predominante. Deve-se sinalizar que 0 Sudão é cortado pelo rio Nilo, característica natural que, como será visto, influenciaria em projetos nacionalistas ${ }^{5}$, apresentando-se, até hoje, como importante fonte de energia e irrigação ${ }^{6}$.

A composição étnica do Sudão, país que tem aproximadamente 40 milhões de habitantes ${ }^{7}$, corresponde a mais de 50 grupos étnicos, que se subdividem em, pelo menos, 570 povos distintos. Os principais grupos (em ordem decrescente) são: árabes, dinkas, bejas, nuers, nubas, núbios, furs, baris, azandes, morus e shilluks. Na região norte do Sudão, verificase a existência de povos árabes e de povos nãoárabes representando, respectivamente, 40\% e 26\% da população nacional; enquanto na região sul do país existem diversas enias de arigem nega que compõem $34 \%$ dos habitantes nacionais. No entanto, dentre os $40 \%$ árabes do norte, muitos se caracterizam, m verdade, por serem

\footnotetext{
3 Além de outras expressões usuais como "encruzilhada" (aosscad) ou "portal da África" (gatenay).

${ }^{4}$ No Sudão a Primeira Guerra Civil ocorreu entre 1955 e 1972; a Segunda Guerra Civil, entre 1983 e 2005; ainda, deve-se mencionar o conflito na região de Darfur, o qual eclode em 2003 e que ainda não chegou ao seu final.

5 Segundo Heather Sharkey (2003), deve-se pensar o Sudão enquanto "unidade hidrológica” para compreender condicionantes políticos no processo de formação do Estado-nação.

${ }^{6}$ A título de ilustração, vale mencionar que, hodiernamente, as principais fontes naturais do Sudão são: petróleo, minérios de ferro, ouro, prata, cobre e zinco. Além disso, o país exporta algodão, goma arábica e gado.

7 Segundo uma estimativa de julho de 2007.
} 
"arabizados", em função de miscigenações ou modos de vida semelhantes (dados retirados de Lesch, 1998, pp.15-17), de modo que uma genealogia árabe objetiva (alegada por movimentos nacionalistas do norte) muitas vezes é ficcional. Já o sul apresenta-se bastante fragmentado, sendo a etnia dinka o principal grupo constitutivo, com $10 \%$ da população total (e 40\% dos povos do sul); ainda, os nuers também se mostram relevantes do ponto de vista demográfico, com $5 \%$ da população nacional.

Quanto à opção religiosa, o Sudão tem 70\% de muçulmanos, 25\% de praticantes de religiões tradicionais (não raro chamadas de "animistas") e 5\% de adeptos ao cristianismo. Dos muçulmanos, metade (35\%) é de árabes, fenômeno que mostra tanto a existência de árabes não-muçulmanos, quanto a existência de grupos negros do sul ou não-árabes do norte convertidos ao Islã. Relativa complexidade revelada por estes dados sociais indica a inexistência de blocos etnoreligiosos homogêneos - não se podendo associar imediatamente árabes a muçulmanos e negros a animistas/ cristãos (muito embora seja uma relação que, em geral, procede) - , o que contraria interpretações simplistas que abordam 0 conflito regional unicamente nesses termos.

A diversidade tem se mostrado um aspecto central na vida sócio-política do país. Contudo, os árabes muçulmanos do vale do Nilo exercem, ao longo da história contemporânea, uma influência desproporcional em relação aos povos do sul nas tomadas de decisões políticas e na definição da identidade nacional do Sudão (Lesch, 1998, p.18). A partir do estabelecimento do Condomínio Anglo-Egípcio, em 1898 - que confere ao Egito o controle formal da região, e à Inglaterra o controle efetivo - , as elites do norte, sobretudo alocadas na administração colonial e nas instituições religiosas, aproveitam-se do aparato construído pelo sistema de colonização e a acabam por tentar consolidar, no processo de formação do Estado-nação, seu domínio sobre os povos do sul.

É nesse período de colonização sob um governo conjunto que se aprofundam as disputas entre as então províncias do norte e as do sul. Ao longo deste artigo, serão identificados, então, os mecanismos impostos pela administração colonial que alargaram a cisão entre as regiões e exacerbaram as assimetrias relativas ao seu desenvolvimento sócioeconômico; bem como sinalizar o papel do colonialismo na criação de estruturas históricas que parecem ter privilegiado os povos árabes em detrimento dos negros do sul, e que agravaram, assim, as hostilidades físicas e simbólicas entre as regiões.

Das elites nortistas, conscientes de seu "arabismo", emergem espaços coletivos de contestação ao domínio colonid, congregados em movimentos macionalistas, que, sustentados por uma herança de cultura árabe comum, bebem de fontes político- 
ideológicas do chamado "mundo árabe" - quais sejam, o pan-arabismo e o nacionalismo árabe territorial - para fundamentar sua luta por independência. Neste sentido, este artigo identificará o desenvolvimento histórico dos movimentos nacionalistas no Sudão, de modo a poder compreender a significância de sua influência política nos rumos para a independência do país. Ainda, será observado de que modo o nacionalismo sudanês relaciona se com a instabilidade política do pós-independência.

Permanecendo à margem da formação do novo governo (sendo sistematicamente excluídos das tomadas de deciñes), os sudaneses do sul acabam por não conferir legitimidade ao Estado em construção no Sudão, de modo que, em agosto de 1955 (poucos meses antes da independência do país, em janeiro de 1956), estoura um motim na cidade sulista de Torit, que vai se desdobrar em uma guerra civil entre o norte e 0 sul. Pela difusão de violência política, manifesta-se, então, a desintegração do projeto de construção do Estado nacional (Idris, 2005). É relevante, assim, realizar uma leitura particular que coloque as tensões regionais em perspectiva histórica, bem como as articule, de modo pertinente, aos profundos conflitos de identidade. A identidade nacional sudanesa e de suas fronteiras culturais são contestadas fervorosamente pelos grupos políticos nacionalistas (Lesch, 1998, p.210), os quais manipulam, de forma metonímica, a idéia de nação sudanesa, para arregimentar mais seguidores e conseqüentemente, fortalecer seu movimento. A incorporação do projeto nacional integracionista árabe, assim como as respostas das ideologias políticas africanistas dão condições a uma configuração monumental da crise política e identitária; por isso, mostra-se indispensável observar o contexto das origens de tais manifestações para entender as razões da deflagração do conflito praticamente intermitente.

Conforme 0 argumento de Amir Idris (2005, p.15), revelase bastante importante realizar estudos que façam uma conexão entre a formação das identidades e sociedades conflitivas - e que se preocupem com a edificação dessas identidades em relação à história e ao processo de formação do Estado nacional. Em resumo, podese perceber a importância de compreender os conflitos no Sudão organicamente relacionados ao processo de construção do Estado-nação, em uma dinâmica constituída por enlaçamentos entre as questões políticas e a formação das identidades culturais. Neste sentido, o artigo propõe-se a identificar os frutos do construto colonial que ensejaram condições para a estruturação de uma sociedade a partir de um eixo eminentemente conflitivo.

${ }^{8}$ A expressão "mundo árabe" será utilizada aqui em alusão aos países árabes pertencentes ao O riente Médio, Vale do Nilo e Magreb, quais sejam, Arábia Saudita, Autoridade Palestina, Argélia, Bahrain, Catar, Egito, Emirados Árabes Unidos, Iêmen, Iraque, Jordânia, Kuwait, Líbano, Líbia, Marrocos, O mã, Síria, Tunísia, além do próprio Sudão. 


\section{2 - 0 Sul nos Projetos Coloniais: 0 Estabelecimento da Southem Policy (1930)}

A Sathem Pdig, política desenvolvida entre 1930 e 1947, foi um marco fundamental dentro do projeto mais amplo da administração colonial em distinguir as regiões norte e sul do Sudão - idéia presente desde a década de 1920 - , com a qual revelava o reconhecimento das disparidades existentes entre elas e propunha, então, um novo horizonte dentro de seu futuro político. Daí deriva a importância em colocar o sul em perspectiva histórica dentro das intenções do colonialismo anglo-egípcio.

Como baliza o sudanês Muddathir 'Abd al-Rahim (1969), há duas fases no que diz respeito ao relacionamento do governo central com a região meridional: na primeira, compreendida entre 1899 e 1919, a postura governamental apresenta-se de modo mais reativo, visando apenas manter a law and arde, auxiliando, para tanto, as dividades das sociedades missionárias cristãs; na segunda, a partir de 1919, o governo mostra-se mais ativo, com atitudes intervencionistas na região, em que se pesem, ainda, os interesses regionais do Império Britânico nos países da África do Leste (tal como Uganda, Quênia e Tanzânia).

Em outros termos, a Inglaterra decreta tal política, em 1930, com base em duas premissas fundamentais: (1) que os africanos negros do sul s̃o cultural e, em alguma medida, racialmente distintos dos sudaneses árabes do norte; e (2) que as três províncias do sul ou iriam se desenvolver como um território separado e soberano ou iram ser integrados à, então, África O riental Inglesa (Wai, 1980, p.378). Ou seja, a política sustentase em linhas africanas, e não árabes, uma vez que seu futuro parecia se residir com a África Oriental Inglesa, e não com o Oriente Médio (Johnson, 2005, p.11).

Com esse fim em mente, o Govemo-Geral programa uma série de medidas de segregação regional e intensifica algumas das disposições já determinadas com a Indireet Rule a razão ostensiva para a política é fazer prevalecer no sul a política administrativa colonial e alastrar efetivamente valores ingleses e cristãos. Para isso, busca se a supressão completa da influência árabe na região (sem as exceções que ainda existiam na década de 20, como a permissão da entrada de comerciantes) que ganhavam terreno no sul; finar as incursões escravistas, de exploração do comércio de gado e de cereais; e refrear o processo de proselitismo ao Islã (Lesch, 1998, pp.32-33) ${ }^{9}$. A política é particularmente levada com

9 Os políticos islamistas do norte passaram a considerar o sul como o "irmão perdido", que deveria ser reintegrado à órbita islâmica com o fim de tal política artificial, e, assim, se poderia novamente superar especificidades culturais e difundir o Islã (Lesch, 1998, p.22). Como aponta El-Affendi (1990), a elite nortista, com essa visão romantizada, além de considerar o sul como uma massa inerte, não levava em conta as 
"mão de ferro" no oeste de Bahr al-Ghazal, onde, como manifestação extrema, os ingleses chegam a expulsar à força os árabes para prevenir o contato entre os povos (Collins, 1983, pp.180-185).

De modo complementar, a Inglaterra visa revitalizar os costumes negros (Wai, p.378), asfixiados, ao menos nas zonas urbanas, pelo processo crescente de arabização. Motivada por um senso de "nacionalismo vitoriano", a administração britânica pretende restaurar a sociedade sulista, por meio de um processo de renascimento cultural (Howard, 1973). Para fortalecer os modos africanos de auto-identificação, o governo necessitava ser completamente informado das estruturas sociais, crenças, costumes, e prédisposições psicológicas da população africana do sul (Wai, p.378) ${ }^{10}$. Deste modo, o governo-geral deseja mais que a simples codificação das práticas heterogêneas existentes (Rahim, 1969, p.70); aspira, na verdade, pela primeira vez estender efetivamente seu poder no sul em função de um projeto político pré-determinado.

Assim, o governo instrumentaliza o conteúdo educacional, tomando-0, também no sul, de caráter técnico com finalidade de substituir os nortstas dos postos de administração, reservando aos missionários cristãos - até então responsáveis por todo 0 processo de instrução na região - somente 0 acesso ao ensino na educação básica (Rahim, 1969; Daly, 2003) - papel ainda muito importante, visto que, como foi dito, desjavam preservar valores cristãos na África do Leste. Além disso, pela Native Cants Ordiname, de 1932, populariza-se o sistema de lukikos (chefes das cortes), os quais existiam desde 1922, ainda que de modo muito esparso (Rahim, pp.79-80). Também, ocorrem melhorias nos sistema de transporte e comunicação, para a consolidação da Native Administration (Ilid, p.80). Ainda, no mesmo sentido, o governo propõe a criação de zonas neutras entre grupos etno-culturais hostis, como os Dinka e os Nuer, por exemplo (llid, p.79) ${ }^{11}$ e deixa 0 comando na região habitada pelos Shiluk nas mãos dos Mkk (chefes tradicionais deste grupo).

Mostra-se pouco controversa a afirmação de que a Sathem Pdigé um momento de inflexão na história colonial do Sudão; entretanto, a avaliøão de seus efeitos é invariavelmente reinterpretada. Torna-se interessante problematizar 0 estabelecimento da

hostilidades pré-existentes à política, nem a composição heterogênea dos povos sulistas; ainda, pressupunha a assimilação pacifica e imediata aos costumes e práticas árabe-islâmicas.

${ }^{10}$ Nesse mesmo contexto, muitos especialistas, como o Prof. Evans-Pricthard e o Prof. Westermann, chegam à região com o intuito de melhor conhecer os povos.

11 Douglas H. Johnson atribui peso à atuação colonial no fortalecimento de conflitos entre os diferentes grupos etno-culturais do sul. Em suas palavras, "a desqualificada percepção do governo de que os Nuer e os Dinka eram inimigos inveterados apenas distorceu e exacerbou as disputas intertribais" (Johnson, 1982. Apud Daly, 2003, p.145). 
Sathem Pdig, por meio de uma leitura crítica, de maneira a verificar suas implicações históricas para a região sul em particular, e para o Sudão e seus movimentos nacionalistas em geral.

Como ponto de partida, é necessário observar o paradoxo histórico com que o sul se depara: a região que tem maior abundância em recursos naturais é, no entanto, a menos desenvolvida do ponto de vista sócio-econômico; isso, para Johnson (2005, p.16), deve-se a dois fatores principais, quais sejam, o relativo descaso colonial e as práticas antgas (anteriores ao Condomínio) de exploração. Com a diferenciação regional, o próprio governo sanciona e participa da exploração de sua periferia, aspecto que não dá condições à voz real ou potencial do sul na direção dos assuntos do país (Ilid, p.16). Deste modo, a divisão histórica existente entre norte e sul teria sido, muitas vezes, exacerbada pela política administrativa inglesa (Hargreaves, 1988).

Na visão de Muddathir Rahim (Apud Lesch, p.33), o dano ocasionado pela política "fanática e arbitrária" do regime do Condomínio no Sudão pes mais que todas as memórias do tráfico de escravos, na medida em que, para a elite nortista, os ingleses e missionários teriam alimentado nos habitantes do sul o ódio contra os árabes e muçulmanos e disseminado uma cultura marcadamente anti-islâmica. No entanto, John Howell (1973) adverte para o equívoco de que considerar a Sathem Pdigy como parte de uma sinistra conspiração imperial provavelmente exagera a ałúcia dos pdig-makes britânicos. Assim, não se poderia atribuir as hostilidades e tensões regionais unicamente às tomadas de decisões da administração anglo-egípcia.

Neste sentido, o sudanês sulista Francis Mading Deng (1995, pp.95-97) pondera as ambivalências do legado do colonialismo no que se refere à questão do sul. Se, por um lado, os nortistas condenavam a Sathem Pdioypor aprofundar as divisões entre o norte e 0 sul e transformar a unidade nacional em um obstáculo; por outro lado, foram os próprios britânicos os primeiros a dar um real significado à unidade do Sudão, o que deveria satisfazer, de algum modo, à elite árabe que vislumbrasse tal projeto.

Para outro sudanês sulista, Dunstan Wai (1980, pp. 378382), a política de insulamento do sul não deve ser criticada em si mesma, uma vez que já não havia uma unidade social e coesão cultural prévia no Sudão, pois os traficantes árabes de escravos teriam invadido e destruído a cultura africana sudanesa, fenômeno que acabava por conferir a tal política, em útima instância, um significado de proteção aos povos meridionais. Assim, a seu ver, a maior crítica que pode ser feita à implementação da Sathem Pdigyé o fato de que ela não trouxe progresso econômico e social ao sul na mesma 
proporção em que levou ao norte, deixando a região, com o fim da política, em 1947, vulnerável aos objetivos nortistas de reincorporação daquela região, alimentados por um sentimento histórico de superioridade.

Como se vê, as vidas políticas das duas regiões percorreram diferentes trajetórias ao longo das décadas de 1930 e 1940. Mesmo com o final da segregação oficial do sul, as histónias sociais do norte e do sul tendiam a se mostrar ireconciliáveis, pois o abismo substancial no que tange ao desenvolvimento econômico que separava ambas regiões, articulado às questões de diversidades étnicas e identitárias, acabava por acirrar as tensões pré-existentes entre os povos. A extrema relevância da clivagem norte-sul revela-se, por exemplo, na posição nuclear que passa a ocupar nos projetos de nação, principalmente do norte ("ponta de lança" dos nacionalismos sudaneses), que, pressionando para o abandono definitivo da Sathem Pdig, convergem na proposição da integaçãa ainda que considerassem os sulistas como cidadãos de "segunda classe"; bem como no ainda discreto nacionalismo do sul, pois a divisão institucional proporcionada pela Sathem Pdigffavorece uma abordagem que proclamava a seessãocomo saída ${ }^{12}$.

Em suma, os mecanismos adminitrativos coloniais dão ensejo a enormes conseqüências para a existência de "identidades concorrentes" (Idris, 2005): as disparidades nos modos de auto-identificacão já existiam desde a época do tráfico de escravos, mas tomaram um aspecto enrijecido como decorrência da dimensão bgal executada pela Inglaterra. Com efeito, os indivíduos e grupos, tanto do sul quanto do norte, acabam por internalizar as identidades criadas pelos colonizadores ao invés de transcendêlas, e são, assim, freqüentemente aprisionados pela linguagem e lógica do pensamento colonial, o que acaba por polarizar profundamente a sociedade (Idris, 2005, p.100). E o conflito armado que vai eclodir em 1955 é a expressão mais concreta de que æria difícil a reparação imediata das instabilidades aprofundadas estruturalmente pelo governo colonial, como é 0 caso da segregação proporcionada pela SathemPdigy.

\section{3 - 0 Desenvolvimento dos N acionalismos Sudaneses (1936-1952)}

Na sociedade sudanesa, o momento do aparecimento de ímpetos patrióticos revelados por indivíduos isolados e da formação de agrupamentos proto-nacionalistas é muito anterior à década de 1930 (verificáveis já no final da década de 1910, nutridos por eventos históricos como o final da Primeira Guerra Mundial e o processo revolucionário egípcio); e mesmo formas mais sólidas de manifestação nacionalista (do ponto de vista da

12 Mais adiante, será visto detalhadamente como a questão do sul insere-se nos diferentes projetos de nação sudaneses. 
organização política e influência social) foram constituídas antes deste período. Contudo, circunstancialmente, somente a partir de 1936 podese observar, sobretudo no norte do Sudão, atos contestadores materializados em entes políticos coletivos, relativamente articulados à sociedade, com projetos de nação de maior alcance e que desempenham um papel importante na desestruturação do Condomínio Anglo-Egípcio, com o propósito da obtenção de independência política; ou seja, no pós-1936 apresentam-se como movimentos consolidados de oposição ao regime colonial.

O momento que dá início à fase de consolidação dos movimentos nacionalistas é, certamente, o Tratado Anglo-Egípcio de 1936, o qual redefinia as relações entre os agentes colonizadores Inglaterra e Egito. O Tratado é assinado em agosto de 1936 devido a motivações extemas: alterações na conjuntura internacional (notadamente a intervenção militar italiana no Chifre da África) estimulavam que se resguardassem os interesses regionais mútuos, empurrando os dois países a um movimento de reaproximação política e diplomática. Um dos tópicos fundamentais do Tratado dizia respeito ao status do Sudão nos respectivos projetos coloniais. No entanto, a questão controversa foi negociada entre os dois países, de modo surpreendente, em pouco mais de uma semana (D aly, 2003, p.51), tendo sido discorrida ponto-a-ponto em seu artigo 11, com concessões a ambos os lados. Em seu processo de formulação, as elites sudanesas são categricamente excluídas da participação direta nas negocáções, bem como têm suas opinões integralmente negligenciadas, havendo, como decorrência, uma ampla desaprovação das disposições do Tratado nos setores sociais. Deste modo, a rejeição ao Tratalo, compartilhada pelos diversos segmentos elitistas, fortalecia o movimento nacionalista como um todo, o que edificaria, segundo o nortista Rahim (1969), de modo processual, uma "nova era" na histónia do Sudão. Assim, o novo tratado entre os colonizadores acaba por ressaltar, para as classes educadas, a importância de apresentar ao governo uma frente suficientemente unida que pudesse reclamar para si um papel de portavoz dos sudaneses (Daly; Holt, 2000, p.124).

Diante desse quadro de descontentamento geral, é fundado o Gradates' Geneal Congess (Congresso Geral dos Diplomados), o qual, baseado no modelo indiano de organização, visa canalizar os esforços coletivos que buscavam o caminho à independência, vendo a si mesmos como embriões de um Parlamento sudanês. 0 Congresso é formado por um grupo seleto de indivíduos educados na Gordon College, instituição desenhada 
pelos ingleses para ser uma virtual máquina de "effendis"13, que iria produzir homens "modernos" que tivessem suficiente familiaridade com os modos britânicos e objetivos para desempenhar trabalhos no regime anglo-egípcio (Sharkey, 2003, p.65). Os estudantes da Gordon College - chamada de "The Eton of Sudan"14 e "Manchester by the Nile" eram inseridos em uma densa atmosfera de "ocidentalização", em função do projeto inglês de aculturação pela educação, de modo que participam de diversas atividades pedagógicas, tal como a prática esportiva que disseminasse a ética dos jogos, que proporcionasse 0 caráter de disciplinação dos corpos e estimulasse a cultura esportiva do ocidente (por meio de hierarquizações, pódios e espírito de equipe); assim, eram ensinados o futebol, o tênis, o tênis-de-mesa e 0 vôlei ${ }^{15}$. Com efeito, os estudantes egressos da Gordon College, formados por uma cultura ocidental, apropriam-se do substrato profissionalizante concedido pela instituição - que os transformava em burocratas de Estado - e, a partir da percepção de que eram líderes na sociedade sudanesa, convertem seu poder político e intelectual no sentido de contestar a dominação inglesa - 0 que acaba por contrariar os interesses iniciais britânicos (Sharkey, 2003). D este modo, a aglutinação de indivíduos desfavoráveis à ordem estabelecida, por meio da elaboração do Congresso Geral dos Diplomados, é sintomática das intenções emancipatórias das elites educadas do norte do Sudão. 0 governo, no entanto, não reconhecia seu papel como corpo político representativo, vendo o Congresso apenas como uma "organização œmi-pública" de caráter filantrópico, relacionada a assuntos públicos, muito embora ambos tivessem mantido, durante os primeiros anos, relações satisfatoriamente amistosas (Rahim, 1969, p. 126) - mesmo porque, até certo ponto, o regime colonial desejiva dialogar com a elite educala para funções administrativas, advindas de suas instituições de ensino.

D eve-se mencionar - fundamentados pela linha de argumentação de Sharkey (2008) - que as políticas educacionais da administração colonial obtiveram consequêencias sociais de longo-termo: os britânicos cultivaram um pequeno grupo de homens que tinham um conhecimento de leitura e knowhowpolítico capazes de desenvolver e articular ideologias nacionalistas; de modo não-surpreendente, estes homens, que levariam a cabo o processo de independência do país, definiram a nação sudanesa conforme sua imagem social, a saber, como uma comunidade árabeisâmica Em uma visão diferente, O’Fłhey (1996)

${ }^{13}$ Effendi é o termo que designa, no O riente Médio, os homens empregados no governo; na Índia, o termo utilizado é Babu; e na Á frica Negra, nativos europeizados.

${ }^{14}$ Em alusão à Eton School, escola famosa e centenária que forma a elite britânica.

${ }^{15}$ Heather Sharkey (2003, p.56), ainda descreve a cultura de vestimentas, de palavras e de imagens (por meio de fotografia e filmes) como ferramentas de exploração e conquista desempenhadas pelo sistema colonial. 
aponta que tais movimentos nacionalistas das décadas de 1930 e 1940 ainda se caracterizavam por serem supra-étnicos: diante do contexto complexo de luta anti-colonial (subjugados por duas nações colonizadoras), os líderes sudaneses, por exemplo, ainda não propunham políticas "islamistas", embora fossem formuladas por muçulmanos.

No conjunto, segundo Sharkey (2003; 2008), são, realmente, os nacionalismos de 1930 e 1940, expressos por meio das abordagens da literatura árabe, que tornam possível falar, pela primeira vez, em "árabes sudaneses". Os proponentes dos nacionalismos adotaram esse uso lingǘstico e expandiram-no, procurando enobrecer o termo "sudanês", como sinal de identidade nacional. Desta forma, desabrocha no Sudão uma literatura propriamente sudanesa e nacionalista (oriunda do norte). Um ponto basal para 0 desenvolvimento de uma literatura que alimentasse os movimentos nacionalistas pode ser identificado em 1927, quando o poeta Hamza al-Malik Tambal manifesta em um jornal de Cartum que o país poderia ter uma literatura árabe distinta, que levasse em conta as especificidades da região. Na busca de uma autenticidade local, escritores tentam retratar os costumes folclóricos do norte do país, por exemplo, como faz o nacionalista Muhammad Said al-Abbasi, o qual relata a vida dos beduínos sudaneses por uma visão romantizada. Ainda, na década de 1940, surgem abordagens que enfatizam a natureza "híbrida" das etnias na nação sudanesa, em articulação com a justificativa de seu projeto de obtenção do poder, mostrando ao govemo colonial que detinham uma visão holística sobre todo 0 territónio. Nesta corrente, nota-se o destaque do literato Muhammad Ahmad Mahjub, um líder nacionalista (que viria a ser Primeiro Ministro) que realça a fusão de traços "indígenas" negros, árabes, turcos, asiáticos, abissínios, egípcios, núbios e magrebinos na constituição da sociedade sudanesa. Por último, podese assinalar, no início dos ars 1950, a proeminência de nacionalistas como Rahman Taha, que almejaram transformar suas idéias literárias em políticas efetivas de libertação nacional ${ }^{16}$. De modo geral, pode-se afirmar que as políticas educacionais inglesas favoreceram 0 aparecimento uma pequena elite letrada e transferem (voluntária ou involuntariamente) o poder para tal grupo monocultural que, consciente de sua alegada identidade sudanesa, produz e aparelha-se de instituições políticas de alcance nacional como é o caso do Congresso Geral dos Diplomados.

O Congresso, composto mais pelos moderados de 1924 do que por adicais unionistas - ainda que estes estivessem lá marcando sua posição política - , é controlado, no início da década de 1940, pelos seguidores do mahdista Rahman. Como se pode observar, o movimento de independência sudanês já apresenta, desde o início de seu processo de

${ }^{16}$ Evidentemente, há uma série de outros escritores e poetas, vinculados com a causa nacional sudanesa, que não foram mencionados. 
consolidação, um complexo amalgama de fatores contraditórios que são ambos indicativos das clivagens sociais existentes (D eng, 1996) - muito embora as divergências políticas e ideológicas estivessem, neste contexto, eclipsadas em favor da sedimentação do Congresso. Em geral, o nacionalismo nos povos subjugados exibe a crença de que fronteiras coloniais encerraram uma comunidade política de pessoas que compartilhavam de uma herança e destino político e, deste modo, as elites nacionalistas sudanesas manipulam a idéia de nação em conformidade com seus interesses grupais específicos, qua seja, nesta conjuntura histórica, estruturar o Estado-nação sob os pilares do arabismo e islamismo (Sharkey, 2003).

De modo assertivo, em 3 de abril de 1942, o Congresso Geral dos Diplomados redige ao governo colonial um memrandumcontendo doze demandas, dando destaque à primeira delas: a autodeterminação do país. Contudo, a administração colonial, por meio de seu Secretário-Civil Douglas Newbold, responde de modo negativo e, enfaticamente, retira qualquer forma de confiança antes creditada ao Congresso. Com a penda de legitimidade que dá ensejo a uma crise intena -, ocorre uma fratura no Congresso Geral dos Diplomados, que se divide em dias alas principais: os "duros" e os "moderados". Basicamente, os primeiros constituíam-se dos indivíduos unionistas - que agiam sob a crença na "Unidade do Vale do Nilo" - e os últimos compunham-se dos velhos adeptos do mahdismo - os quais operavam sob o lema "Sudão para os Sudaneses" - , fenômeno que implica no fim do movimento nacionalista não-sectário (Rahim, 1969) que existia antes, ainda que acordado tacitamente. Ambos sustentavam-se na politização nacionalista do arabismo (sentimento de pertencimento histórico e cultural ao mundo árabe): os primeiros apoiavam-se em princípios ideológicos pan-arabistas; enquanto os últimos amparavam-se em bases políticas territoriais (Deng, 1996) ${ }^{17}$. A fissura entre líderes religioso-políticos provocou um impacto debilitante na vida política pré-independência, o que desemboca na época pós-colonial na existência de "feudos estéreis de sectarismo" (Maghoub, 1974).

De modo subseqüente, no processo de faccionalização do nacionalismo, formam-se partidos políticos correspondentes a cada projeto de nação, sendo o primeiro deles 0 Partidb Ashigga de 1943, sob o comando de Imail Azhari (militante pró-Egito) ${ }^{18}$, que recebe sustentação financeira de indivíduos egípcios, e que ganha apoio político do unionista histórico Mirghani. Em 1945, sob a direção de Rahman, constitui-se o Partidb Umma (que significa Partido do Povo), financiado majoritariamente pela família Mahdi, o

17 Ver Hasabu; Majid (1985).

${ }^{18}$ Azhari, professor da G ordon College, estuda em Beirute e volta influenciado pelas idéias pan-arabistas. 
qual pregava a independência completa do Sudão e obtinha, com esse apelo, maior adesão popular (D aly; Holt, 2000, p.127) - muito embora os nacionalismos, seja na sua vertente pan-arabista, seja na sua vertente sudanesa, nunca tivessem conseguido real apoio das massas (Johnson, 2005).

No meio tempo da formação dos principais partidos, entre 1943 e 1945, a administração colonial estabelece o AdkisaryCannil for Nathem Sudan Ordar, com 0 objetivo de realizar acondos com os nacionalistas do Sudão, como tentativa de revitalizar o campo das negociações. Entretanto, tal conselho consultivo mostra-se pouco representativo, contando com a participação de membros sudaneses ligados de alguma forma ao regime colonial (Ki-Zerbo, 1972) e, portanto, não adquire nenhuma legitimidade frente àqueles primeiros movimentos.

O utro fator importante para a solidificação dos nacionalismos sudaneses é 0 término da Segunda Guerra Mundial, na qual os africanos como um todo, mas os sudaneses em especial, desempenharam um papel muito mais dieto que na Primeira Guerra: por exemplo, tropas sudanesas atuaram, em 1941, na Batalha de Keren, onde, com uma força mista inglesa e indiana, ajudaram a combater os italianos na Eritréia. No conjunto, a Segunda Guerra contribui para o fortalecimento dos nacionalismos na medida em que ajuda a difundir uma mentalidade anti-colonial, por meio dos contatos com outros povos, bem como pela massiva propaganda política de defesa da descolonização por parte dos Estados Unidos e da União Soviética, protagonistas da nova ordem internacional que se estabelecia. Além disso, havia a influência concreta da Carta do Atlântico, de 1941, e da Carta das Nações Unidas, de 1945, as quais alimentavam nos povos da periferia do sistema internacional o espírito de autodeterminação, democracia e liberdade (ao menos no plano formal e nas suas acepções odidentais contemporâneas), como se sentissem obrigados a garantir aos africanos uma compensação política, econômica e social em troca de seu esforço na guerra (Coquery-Vidrovitch; Moniot, 1976, pp.125-126).

De modo específico, o fim da Segunda Guerra tem grande impacto no Sudão, uma vez que coloca na mesa, novamente, a questão do status da soberania no país. Assim, 0 Egito - que pela primeira vez estava interferindo de modo mais efetivo nos assuntos de política doméstica em toda a histónia do Condomínio - propõe formalmente renegociar 0 Tratado de 1936, como forma de concessão política inglesa, dada a primazia de Suez nos seus interesses estratégicos (Johnson, 2006), tendo conseguido formar, assim, em março de 1946, uma delegação supra-partidária sudanesa para negociar no Cairo. As negociações, no entanto, rompem-se em janeiro de 1947, devido à pressão egípcia para a união definitiva 
com o país, e, para tanto, reconhece somente os unionistas como porta-vozes do Sudão; e a Inglaterra, por sua vez, tenta frear os ânimos dos nacionalistas unionistas, valorizando, em contrapartida, os agentes defensores da saída política com base na territorialidade, dando seu apoio ao Umma para se opor aos anseios egípcios, ao preço do progresso constitucional acelerar-se (Woodward, 1981) ${ }^{19}$.

Enfim, o processo de construção do Estado-nação sudanês levado a cabo pelas elites letradas nortistas, fragmentadas em duas metades, produz uma identidade nacional como resultado da sua luta contra domínio colonial, modelada na medida em que as facções nacionalistas representativas participaram das ações contestadoras e dividiram os frutos da independência (D eng, 1996, p.101).

\section{4 - 0 Sul nos Projetos N acionalistas}

O governo colonial, desde 1946, calcula a necessidade de constituir uma Assembléia Legislativa que representasse todos os sudaneses, dentro de uma estratégia mais ampla de concessão gradual de independência, por meio de uma evolução política que se mostrasse prudente $^{20}$. A implantação de uma Assembléia nacional exigia que se reconsiderasse, então, a política para o sul, na medila em que ela se propunha representativa de todos os sudaneses. A discussão sobre o status da região meridional e sua participação na Assembléia ocorre em dois momentos, quais sejam, a Sudan Administration Confeerce realizada em Cartum, em abril de 1946; e a Conferência de Juba, ocorrida na cidade sulista de mesmo nome, em junho de 1947.

De modo decisivo, os movimentos nacionalistas do norte acreditavam - ainda que, muitas vezes, de modo velado - que o sul do Sudão era necessário para a prosperidade do país (Johnson, 2006, p.24), ambicionando, então, obter o controle efetivo sobre aquela região. Ainda, os nacionalismos - tanto na sua vertente unionista, quanto na "sudanesa" convergiam no ponto de que a Sathem Poligy alimentava o particularismo separatista ao invés do nacionalismo unificado sudanês; e, por isso, era imprescindível construir a unidade política em torno de um só território nacional. Os principais poligy-makess tal como Ismail Azhari, advogavam pela predominância da orientação "arabista" dentro do Sudão, indiferentemente da diversidade étnica do país (Gatkuoth, 1995); a unidade nacional, por

${ }^{19}$ Este se mostra um momento histórico bastante tenso, ocorrendo muitos conflitos entre partidários, suscitados, em especial, pelo descontentamento do Partido Umma com o encaminhamento da questão.

${ }^{20}$ Ainda, outro fator definidor da mudança de rumos na política inglesa para 0 sul do Sudão refere-se à proposta de revisão do tratado de aliança com o Egito assinado em 1936: uma das demandas dos egípcios dizia respeito à incorporação integral dos territórios sudaneses à soberania egípcia. Tal mudança de conduta servia de pretexto à Inglaterra, dando condições ao que Sarkesian (1973) denomina de "NewSathemPdig". 
meio da incorporação do sul, poderia ser escorada no processo de arabização, de modo que se criasse um sentimento de coesão dentre os habitantes heterogêneos do país, pela sua absorção gradual ao mundo árabe. 0 Congresso Geral dos Diplomados, pólo aglutinador dos desejos independentistas, argumentava (ainda no período da Sathem Pdigy) que as escolas do sul não deveriam mais ter missionários cristãos, mas sim precisavam ser abertas à cultura árabe-islâmica, de modo similar ao que ocorria no norte; o projeto de arabização orientava para 0 abandono das linhas africanas dos modos de vida no sul ${ }^{21}$. 0 projeto "civilizatório" de homogeneização etno-cultural indica a forte versão assimilacionista do modelo de Estado-nação proposto pela elite árabe do norte, que acaba por definir as linhas de clivagens políticas por todo o país (Lesch, 1998).

Deste modo, a partir dos projetos políticos de incorporação do sul proclamados por ambas vertentes nacionalistas do norte, delineiam-se características históricas do Estado sudanês que vão se concretizar no pós-1946, na medida em que a cultura política mainstreamreforça o mito do Estado unificado (fundamentada em uma espécie de "direito divino"), ocultando desigualdades regionais, de modo que legitimasse sua versão inventada de Estado-nação (Idris, 2005).

Como adverte Lesch (1998), na agenda da Conferência de Juba não estava presente a questão "unidade-separação" da região meridional (a opção pelo projeto unificador já havia sido definida unilateralmente no Adkisary Camil), mas sim se encontrava na pauta a maneira como o sul seria representado na Assembléia Legislativa: em termos de números de representantes (seriam, por exemplo, reservadas $14 \%$ das cadeiras para representantes do sul), bem como a definição das especificidades de suas competências legais e quais seriam as salvaguardas especiais para a região. A Conferência de Juba, contando com a presença de poucos representantes sulistas (novamente ligados à administração colonial), reitera que "é do desejo do su estar ligado ao norte" e executa a decisão do Sudão administrado em um só país, apenas endossando disposições antes indicadas pelos oficiais coloniais. Para tanto, o govemo implanta diversas medidas para promover um senso de identidades compartilhadas entre os povos do norte e do sul, mas, de modo mal-sucedido, não consegue alterar substancialmente as atitudes de hostilidade mútua. Ao contrário, a decisão colonial acaba por agravá-las - uma vez que o passado de animosidades e exploração, se por um lado aprofundava as desconfianças do sul com relação ao norte, por outro, alimentava uma visão de superioridade intrínseca do norte em relação ao sul - de modo que a reversão da Sathem Pdigymarca um novo capítulo nas relações afro-árabes no

${ }^{21}$ Os governantes sudaneses tentaram colocar efetivamente essa política em prática no regime militar de Abboud (1958-1964). 
Sudão (Wai, 1980, pp.382-385). Com uma percepção astuta que ilustra bem o papel histórico do sul do Sudão nos projetos coloniais e nacionalistas (do norte), o govemador da província de Bahr al-G hazal, à época do final da década de 1940, reporta ao governador de Equatoria (ambas províncias meridionais) que o sul caracteriza-se apenas como uma peça no jogo da política de poder de outros atores, e seu destino, portanto, não se encontraria no terreno da moralidade, evidenciando o descaso colonial e das elites do norte quanto àquela população.

Contudo, a Conferência de Juba, que insinua a "infantilização" do sul, assegura, pela nova configuração política e territorial, a sua participação na Assembléia Legislativa. Deste modo, realizam-se as primeiras eleições em 15 de novembro de 1948, a qual acaba por adquirir pouca legitimidade, em virtude de sua baixa representatividade, uma vez que os unionistas, descontentes com a postura dúbia inglesa, acabam por boicotar o pleito.

Mais adiante, em 1950, a Inglaterra recebe uma forte pressão dos Estados Unidos para que fosse feito um tratado com Egito que assegurasse os interesses do bloco ocidental no Canal de Suez, o que acaba por provocar, desta vez, medo nos partidários do Umma, os quais temiam 0 abandono britânico da sua posição no Sudão, de tal maneira que clamam por auto-govemo e independência imediata. Nesse contexto de potencial reaproximação entre Inglaterra e Egito, nasce um mvo partido forte com intençõe unionistas, capitaneado por Mirghani, o National Front (que depois vai se transformar no National Unionist Party, o NUP).

A partir do estabelecimento da Assembléia Legislativa, os representantes do sul, convencidos da relevância da política nacional embrionária proveniente de Cartum, passam a rejeitar a idéia de "tutela" do sul e se dispõem, pelas lideranças de Siricio Iro, Philemon Majok e Buth Diu, a um engajamento político saliente naquele espaço (Howell, 1973). Contudo, a consciência política no sul ainda permanecia relativamente baixa, e, assim, os poucos representantes sulistas não conseguiam formar uma retguarda política na sociedade meridional para aturem com suficiente coesão e cœrência nos fóruns públicos $^{22}$. De todo modo, paulatinamente, foram surgindo, com pequenos grupos de amigos, associações políticas informais dentre os povos do sul - não raro em função da percepção de que o norte os "assaltava culturalmente", bem como explorava seus recursos naturais (Sharkey, 2003) -, aumentando, assim, os víncubs culturais e identitários,

${ }^{22}$ Howell (1973) menciona que, nas vilas e campos pastoralistas do sul, existiam algumas canções populares que demonstravam hostilidade aos árabes e ridicularizavam europeus, mas nada que refletisse realmente algo que ultrapassasse a consciência dos pequenos grupos; os conceitos de ser sudanês ou ser africano não pareciam existir na mentalidade da maioria das populações daqueles povos (embora dentre os povos dinka 0 sentimento de nacionalidade se apresentasse com mais recorrência). 
construindo novas lealdades políticas e consolidando formas de organização social e atuação nacional. No conjunto, com o desejo do sul de maior inserção nos espaços públicos e como consequiência da distribuição desigual de poder e privilégios entre as regiões, a identidade nacional sudanesa vai sendo definida e assentada (Idris, 2005).

\section{5 - A Caminho da Independência: 0 Estado-Nação em Construção (1952-1956)}

Neste cenário de novos relacionamentos entre a administração colonial e as elites nacionalistas (e também entre Inglaterra e Egito), pode-se estabelecer um nexo crucial para a compreensão dos desdobramentos históricos que vão modelar a estrutura da sociedade sudanesa. Diante desse momento de apreensão quanto ao futuro do país pelos diversos lados envolvidos, a administração colonial chama, em 1951, a Constitutional Amendment Comission com a finalidade de que se omeçasse a pensar em um estatuto para 0 autogoverno do Sudão; assim, a comissão recebe apoio somente por parte do Umma, sendo boicotada pelo Partido Ashigga e pela confraria da Khatmiyya (os quais não abriam mão do projeto de união com o Egito).

Um ponto importante de inflexão deve ser destacado: como reação ao medo da marcha acelerada para secessão sudanesa (KiZerbo, 1972, p.310), o Egito evoga definitivamente 0 já desgastado Tratado de 1936, proclamando, então, o Rei Faruk 0 soberano do Sudão e elaborando, assim, uma nova Constituição para o país. Tal ato unilateral é rejeitado veementemente pela Inglaterra e pelo governo colonial sudanês, obtendo, como era de se esperar, apoio somente dos adeptos do Ashigga. Como o Egito havia revogado o tratado - ausentando-se, portanto, do domínio conjunto -, não podia rejeitar a proposta de construção do Estado sudanês, formalizada pela Inglaterra com 0 Seff-Gouemment Statute, de 1952. Tal projeto britânico vislumbrava, no médio-prazo, um regime de autonomia ao Sudão (Ki-Zerbo, 1972, p.311; Daly; Holt, 2000).

Há nesse contexto um outro evento disruptivo nos rumos que vão definir o que vai ser o futuro do Sudão, qual seja, o movimento político no Egito que, capitaneado por uma "sociedade secreta" de oficiais egípcios, liderados por Nequib e Nasser, derruba o Rei Faruk em julho de 1952, os quảs, além de tomar o poder, rompem com o passado monárquico pelo colapso da ordem no país. A ruptura parece fundamental para entender a derrota do unionismo na medida em que os novos governantes renunciam aos anseios históricos de união com o Sudão (Johnson, 2006, p.22), enfraquecendo definitivamente a inserção de tal projeto no plano doméstico sudanês. 
Com os novos governantes no poder, em 1953, é firmado um novo Tratado AngloEgípcio, proposto pelo Egito e aceito pelos partidos sudaneses (mesmo pelo NUP, agora relativamente enfraquecido e desideologizado), que estabelecia um período de transição de três anos de auto-govemo à independência política, em grande medida, em virtude da compreensão, por parte da metrópole, do caráter irreversível do processo; e da percepção, por parte das elites nacionalistas, que a negociação seria a melhor escolha - mesmo porque elas depositavam confiança no acesso às instituições já existentes (Coquery-Vidrovicth; Moniot, 1976, p.124).

Como decorrência, em 1953, realizam-se as primeiras eleições legidativas não boicotadas por nenhum partido. 0 resultado eleitoral, do ponto de vista quantitativo, foi 0 seguinte: das 97 cadeiras, 50 para o NUP; 23 para o Umma; 12 para independentes; 9 para o Partido do Sul; e 3 para o Socialist Republicans (partido de curta vida com inspiração conservadora - embora se utilizasse do adjetivo "socialista" - , composto, em sua maioria, por indivíduos ressentidos com Rahman). A preferência pelo NUP reflete, nesse momento, muito mais que o desejo de unão com o Egito - idéia agora desgastada -, mas sim manifesta a grande rejeição à Inglaterra, com a qual o Umma mantinha laços estreitos, a fim de alcançar a independência ${ }^{23}$. O Parlamento, enfim, abre em janeiro de 1954, com Ismail Azhari como Primeiro-Ministro, sob um clima relativamente violento nas cidades.

No que diz respeito à questão meridional, os representantes do norte rejeitam a criação do posto de Ministro do Sul no novo governo (Johnson, 2005, p.26), e o sul, já excluído das negociações com o novo governo egípcio e com a Inglaterra, tenta pelas vias institucionais - embora não tivesse acesso numérico significativo a elas - estabelecer 0 Federalismo como solução constitucional, formando, então, o Partido Liberal. Ainda, em outubro de 1954, em Juba, é realizada uma conferência das elites nacionalistas do sul para discutir o futuro do Sudão em geral, e do sul do Sudão em paticular, chegando a uma conclusão que apontava para a autonomia urgente da região. 0 descontentamento do sul (em especial dos povos de Equatoria) com o processo eleitoral e seu resultado - no qual, como em todas as outras instâncias, eles foram sub-representados - dá condições a revoltas generalizadas por parte da população sulista.

As demandas sulistas por reestruturação do sistema político dão ensejo à abordagem federativa, que defende maior autonomia do sul nas decisões políticas relativas

${ }^{23}$ Vale mencionar que o NUP, nessa época, embora vitorioso nas eleições, passa por um momento de desmontagem, na medida em que havia se desideologizado. Mesmo o líder Azhari abandona gradativamente a concepção de união com E gito. 0 partido, assim, não consegue superar suas faç̧ões personalistas, que, de modo oportunista, tinham como objetivo apenas a satisfação de interesses particulares. 
à independência, inspirada nas linhas canadenses de binacionalismo (Heraclides, 1987). Em contraposição à ideologia dominante de "arabidade" - critério para prestigio nacional, tomada de decisões, autoridade e liderança intelectual (Idris, 2005) -, agentes políticos sulistas fundam, como dito, em 1954, o Partido Liberal que, optando pela alternativa federalista, trilha um caminho, ao menos até 1958, que se confunde com a história do próprio sul do Sudão (Howell, 1973). 0 partido nasce do descontentamento dos sulistas em relação aos resultados do Sudanisation Committee (comitê para acelerar a "sudanização" dos postos político-administrativos chaves no país) e com o crescimento da militância anticolonial dentro das classes urbanas do sul. No que se refere ao comitê, estabelecido entre 1953 (pelo AngoEgptian Agremet of Seff-Detemination for theSudan) e 1955, dos 800 postos à disposição apenas quatroforam encarregados a indivíduos da região sul. Esta manifestação incontestável da sub-representação dos sulistas no caminho para a independência desemboca na radicalização de movimentos políticos, agora mais inclinados à separação completa do Sudão (discurso fortalecido na era póscolonial), como será abordado a seguir ${ }^{24}$.

Mostra-se com clareza a dificuldade de se estruturar um sistema constitucional que respeite igualmente as regiões e contemple com isonomia os diferentes cidadãos (Lesch, 1998). Deste modo, como informa Amir Idris (2005), surgem plataformas políticas distintas entre os nacionalismos do norte e do sul, que manifestam dsausos de integração nacional ou de separação do sul em relação ao norte - de modo sempre articulado a categorias étnicas e raciais. A defesa da integração embasase na crença firme da "diversidade com unidade", e apregoa a luta pan declarar ilegais barreiras onstitucionais e prevenir oportunidades iguais. Este discurso forjaria um interesse comum das regiões (ou etnias e raças), amparado em reformas democráticas dentro do contexto de um Estado racializado (sustentado pelo arabismo) (Idris, 2005). Em concordância com o argumento da integração, Muddathir Rahim (1969) crê que a diversidade étnica e religiosa não é determinante para a separação em dois Estados; para ele, os Estados modemos não poderiam se basear em homogeneidades (religiosa, étnica ou cultural) para formar-se, mas sim nos interesses da comunidade, de modo que as minorias fossem incluídas nela. Já o discurso da separação, profundamente cético na transformação democrática, assume a importância e a realidade

${ }^{24}$ Cabe mencionar, com base no artigo de John Howell (1973), que outra tendência em meados dos anos 1950 é a emergência de um movimento político ativo nas escolas de segundo grau. Segundo ele, a maior parte da primeira geração de líderes políticos vinha das escolas missionárias católicas e protestantes (ainda havia poucos que freqüentavam escolas em Uganda), mas, quando da fundação da primeira escola secundarista no Sudão, em 1948, em Rumbek, na província de Bahr al-Ghazal, aflora um importante campo de novas lealdades políticas, ideias e líderes; um grande número de "Rumbek Boys" ingressaram na universidade e, nos anos 1960, tornaram-se líderes de movimentos a favor da causa sulista. 
das categorias étnicas e raciais existentes; os líderes proponentes de tal tese, sobretudo sulistas, percebem a etnicidade como sendo ahistórica e criticam os integracionistas por sua tendência a preservar o status herdado do colonialismo. No entanto, para Idris, há uma similaridade evidente entre os dois discursos: ambos são informados pela noção de que 0 principal problema enfrentado pelos oprimidos é a realidade de raça e etnicidade; e, portanto, sua fraqueza expressa-se por não transcender essas categorias. Além disso, os projetos teriam como aspecto problemático o fato de serem freqüentemente aprisionados pela lógica do pensamento colonial, ainda que sua grande parte de sua inspiração cultural viesse da África negra (no caso do sul) e do Oriente Médio (no caso do norte) (Ruay, 1994).

\section{1 - A Explosão dos Conflitos}

Diante deste clima enfrentado no "contestado Estado-nação sudanês" (Lesch, 1998), permeado pela atmosfera de insegurança social no sul e recrudescimento das ações políticas nortistas, irrompem manifestações violentas que expressavam a insatisfação dos povos sulistas em relação à condição que teriam no novo governo, dando ensejo à guerra civil - além da "guerra de visões" (D eng, 1996) - que vai persistir por décadas. A explosão dos conflitos inicia-se em agosto de 1955, quando unidades militares negras sublevam-se contra 0 jugo do norte árabe, no motim de Torit, em um movimento não-organizado e não-coordenado que se espalha para outras guarnições no sul (Johnson, 2006, p.27-28), como contestação a sua condição de "apêndice estranho ao resto do país" (Ki-Zerbo, 1972, p.312). 0 estopim havia sido um telegrama falso de Azhari, supostamente ordenando que os administradores nortistas - presentes novamente em grande quantidade no sul - fossem impiedosos com os habitantes sulistas; tal fato que aniquila então, a solução pela via institucional, pois os representantes legais nos fóruns públicos não haviam conseguido mobilizar os descontentes, os quais (dinkas e nuers, particularmente) os viam também como parte do aparato coercitivo da administração colonial Johnson, 2005, p.28). A Inglaterra recusa-se a atuar para por fim ao conflito, pois, para tanto, teria que agir em conjunto com Egito e não queria aumentar, eventualmente, a influência e poder egípcios. Deste modo, fica apenas a cargo do próprio exército sudanês a tarefa de reagir aos insurgentes, o que dá início a guerra civil entre o norte e o sul do Sudão ${ }^{25}$.

${ }_{25}$ Ainda, no mesmo mês, há muitos protestos em Zande, contrários à prisão política de um membro do parlamento favorável à solução federalista, o que desencadeia intensa repressão governamental; também, em Yambio, em função dos problemas econômicos locais, ocorrem demissões em massa dos trabalhadores, 0 que aumenta a onda de greves e, conseqüentemente, a atitude repressiva governamental (Lesch, 1998). Em 
Essa situação de protestos dos excluídos das transformações políticas, as quais são encaradas como ilegítimas, mostra nitidamente uma situação em que um só grupo étnico impõe seus valores e símbolos na forma de "nacionalismo étnico" ao país, ao invés de abraçar um "nacionalismo ternitorial inclusivo" que circunde os povos diversos do país (Ihid, p.37). Para Dunstan Wai (1980), nem os próprios colonizadores perceberam a dimensão de 1955: não teria significado exclusivamente um motim, mas sim uma reafirmação nacionalista responsável do africanismo sulista sobre a hegemonia árabe ${ }^{26}$.

No final, o processo de independência representa para o sul apenas uma "troca de mestres" (Ruay, 1994), ou seja a região meridional abandona a situação de sujeição à Inglaterra e ao Egito, mas, em contrapartida, toma-se refém dos desígnios do norte, o que configura uma espécie de "colonialismo interno" (Hetcher, 1975) ${ }^{27}$. 0 conceito refere-se a desigualdades políticas e econômicas entre regiões dentro de uma mesma sociedade, para descrever a ação exploratória de um grupo sobre outro; a relação entre a região dominante e a subjugada se estabeleceria de modo similar à que ocorre entre colonizador e colonizado, sendo que, também aqui, a extração de riqueza seque o fluxo da periferia ao centro do país e se sustenta por meio de mecanismos políticos de exclusão. Tal modo de relacionamento mostra-se perceptível no caso do Sudão, particularmente no caminho para a independência.

Neste sentido, cabe salientar que, depois do motim de 1955, tortura de toda espécie são diariamente infligidas a prisioneiros por todo o sul; também, sudaneses do sul são enviados ao norte para trabalho forçado em prisões, enquanto outros conseguem fugir para a fronteira com Uganda (Meyerowitz, 1963). Para Idris (2005, p.45), a resposta desproporcionalmente repressiva da administração central é apenas a mais recente e brutal manifestação dos esforços árabes para impor sua hegemonia política e cultural em face das demandas africanas por completa participação política. Além disso, a seu ver, a violência no pré-independência demonstra fracasso do movimento nacionalista en transcender identidades étnicas e raciais. De todo modo, no sul, a manifestação de consciência nacional parecia ter sido confinada às grandes cidades, onde os grupos etno-culturais se misturavam;

novembro de 1955, os representantes sulistas declaram que não endossariam a proclamação de independência a menos que obtivessem status federal. No fervor do momento pré-independência, o primeiro-ministro Azhari, tentando alargar suas bases políticas, promete repensar a questão federal, prometendo colocá-la em votação na futura casa legislativa.

${ }^{26}$ Existem ainda outras interpretações, como a de Rahim (1969), que, de um certo modo conspiratório, acredita que a revolta foi incitada pelo Egito que queira bloquear independência do país, dada a derrota do projeto unionista.

27 O colonialismo interno ainda poderia ser verificado, segundo Gouldner (1978) ao longo da história nos seguintes lugares: além do Sudão, África do Sul, Tailândia, País de Gales, Quebec, Áustria-Hungria, Escócia, Bangladesh, "Chicanos" nos EUA, Palestinos em Israel, e União Soviética (objeto central de seu estudo). 
as "nações nilóticas" - como a dos dinka, por exemplo - desempenharam apenas um papel periférico neste período imediatamente anterior à independência (Howell, 1973).

Conforme ilustra Gatkuoth (1995), o Sudão é caracterizado por um alto grau de pluralismo social, um baixo nível de integração nacional e desigualdades marcantes na distribuição de recursos entre as regiões e comunidade étnicas. Sob tais circunstâncias, as clivagens tornam-se fontes de tensão e ameaça à estabilidade da administração central. Estas são dissimilaridades significantes, embora não insuperáveis, que enfraqueceram as conexões conceituais do Estado-nação. O Estado não pode ser identificado com um conjunto de símbolos que representam exclusivamente um ou poucos componentes das populações. O Sudão, para ele, é o caso extremo do fracasso da construção de uma nação.

No conjunto, o motim serviu para acelerar, ao invés de atrasar, o processo de independência do Sudão. Assim, diante desse quadro, o Parlamento sudanês, em fins de 1955, requer a evacuação imediata dos ingleses e egípcios de seu território, com Rahman e Mirghani, antigos rivais polítcos, articulando um governo \& coalizão no pós independência. Em 19 de dezembro de 1955, eles redigem a declaração de independência, que é atingida efetivamente em 1 de janeiro de 1956, quando todos os símbolos do governo conjunto são destruídos (Daly; Holt, 2000, p.141) ${ }^{2}$, muito embora as questões de nacionalidade ainda não estivessem resolvidas (Johnson, 2006, p.29). Se, no contexto de descolonização, a busca de identidade é a dinâmica básica da política africana (Ferkiss, 1966, p.11), o caso do Sudão rão é diferente ${ }^{29}$. A ausência de vínculos culturais harmoniosos não produz nenhuma espécie de coesão social entre os povos do norte e do sul, e, desta maneira, a falta de senso de lealdade nacional no processo de formação do Estado-nação exige que, seja pela pespectiva do arabismo ou pela do africanismo, resgatem-se temas e elementos revitalizadores dos respectivos modos de auto-identificação, de tal maneira que o "ser" sudanês se apresenta como permanente objeto em disputa. Uma disputa traduzida em termos de violência generalizada.

${ }^{28}$ Rahman al-Mahdi diz que $1^{\circ}$ de janeiro de 1956 marca a ressurreição do Sudão depois de 70 anos de mahdismo. Segundo Marghoub (1974) e Warburg (1993), o líder teria chorado na cerimônia de independência.

${ }^{29}$ Q ue, embora com todos os seus dilemas, junto com a Nigéria, seria um país comparável à Costa do O uro no que diz respeito à preparação pra independência (Hargreaves, 1988) 


\section{6 - Árabes e Africanos: A Luta pelo Ser Sudanês}

Esta parte do artigo tem como objetivo observar a crise de identidade nacional entre os povos do Sudão que complicou a formação de um sistema político que garantisse proteção social aos diferentes grupos étnicos. Será identificado como as duas linhas de demarcação cultural no país, quais sejam, árabes e africanos - linhas que, para além do caráter étnico, envolvem fatores lingüísticos e religiosos de distinção (Lesch, 1998, p.19) constroem historicamente suas marcas identitárias em função das características do outro. A "fratura afro-árabe" desvelase, de modo interrelacionado, tanto na questão da formação das identidades coletivas, quanto no processo político-constitucional de nationbuilding e acaba por reforçar perspectivas dicotômicas. Tal abordagem "binarista" (ainda que não se possa desconsiderar a existência dos dois pólos) recria realidades sócio-culturais como sendo essencialmente antagônicas e estáticas, acentuando, assim, para cada grupo étnico (ou região), percepções falseadas sobre si, contrapostas à imagem do outro. Como sugere Francis M. Deng (1996), as auto-percepções altamente subjetivas, são, com recorrência, afirmadas em termos de objetividade racial e genealógica (ambos fazendo "vistas grossas" aos contatos sociais que acarretaram em miscigenações étnicas e mútua recepção cultural), fato supostamente evidente que daria legtimidade a políticas de dominação.

Com efeito, a ascensão política e social árabe sustentase na ideologia da sua supremacia cultural e racial em relação aos negros do sul. As expressões históricas das relações desiguais entre ambos justificariam a estruturação da sociedade sudanesa em termos hierárquicos, bem como 0 alargamento da cisão norte-sul (muito embora ocultada nos discursos governamentais) - uma representação conceitual recente, como afirma Voll (1991. Apud Lesch), inventada por decreto imperial e aprofundada com $\infty$ decisões políticas pós-coloniais. Então, será tratado como se desenvolve o processo de arabização que deseja apagar as particularidades e homogeneizar o país - e 0 aparecimento da reação africanista, para compreender como se formam as identidades no bojo da construção do Estado-nação. 0 projeto de difusão dos modos de vida árabes, sancionados pelas políticas de Estado, falha em criar um terreno seguro para coexistência pacifica entre os povos e regiões, na medida em que muitos líderes políticos, crentes na superioridade do arabismo, não aspiram uma reconciliação das distintas realidades étnicas e culturais, por meio da participação real dos excluídos na esfera pública.

Por último, serão abordadas as diferentes visões dos autores quanto à articulação da crise das identidades nacionais sudanesas e processo de formação do Estado-nação, 
identificando seus focos (quanto à configuração social, política e cultural do país), suas perspectivas ideológicas e proposições a modelos do Estado.

\section{1 - Identidades em Conflito}

A discussão sobre o tema das identidades exige que se examine, ainda que de modo relativamente panorâmico, algumas apreciações conceituais de modo a situar o caso sudanês no debate teórico. Conforme apresenta Francis M. Deng (1996), a concepção de identidade utilizada em sua obra referese "às maneiras em que indivíduos e grupos definem a si mesmos e são definidos pelos outros com base na raça, etnicidade, religião, linguagem e cultura"; para ele, quaisquer que sejam os fatores determinantes, identidade é um conceito que proporciona ao individuo um significado psiølógico e social profundamente enraizado no contexto dinâmico grupal; em contextos de violência decorrente de crises identitánas, a seu ver, a fonte do corflito não vem da diferença (tomada como incompatível), mas ocorre quando grupos rebelam-se contra o que vem como intolerável opressão pelo grupo dominante (na formação do Estado-nação), freqüentemente expressa como negação de reconhecimento, marginalização e talvez até ameaça de aniquilação cultural ou até eliminação física ${ }^{30}$.

Como bem lembra Ann Mosely Lesch (1998), corre-se, freqüentemente, o risco de reificar diferenças étnicas e religiosas - as quais não se encontram em blocos monolíticos fazendo-as parecer desnecessariamente rígidas e permanentes. Deste modo, os conteúdos de pertencimento podem ser associados e, dependendo de conjunções históricas, pode-se construir novos laços identitários intercambiáveis. Esta perspectiva, em consonância com a visão de John Armstrong (1982. Apud Lesch), denota que identidades sociais são inerentemente situacionais e em fluxo (manipuláveis, inclusive), embora se ressalve a necessidade de haver précondições, ainda que não-fixas, para a fundação de uma identidade nacional. O u seja, o sentimento de pertencimento, expresso por categorias de identificação nacional, seria, de fato, embasado em semelhanças históricas e reais.

Um dos indicadores de conexão sócio-nacional que proporciona percepções de identidade comum pode ser a etnicidade. A literatura relativa às etnicidades - vasta na área de Antropologia - trata do tema sob diferentes primas: o termo etnicidade surge na língua inglesa na década de 1950 ("ethnicity") e adquire significados diversos, ainda que existam alguns elementos básicos que caracterizam a etnicidade enquanto tal (Hutchinson; Smith,

30 Para compreensão de diversos conflitos étnicos relacionados ao Estado-nação, ver Stavenhagen (1996). 
1996). Contudo, segundo definição de Fredrick Barth (1969. Apud Lesch), ela pode ser identificada pela "ampla autoperpetuação biológica, compartilhamento de valores culturais, matriz de interação e comunicação, membros que identificam a si mesmos como distinguíveis de outros". Embora o conceito de etnicidade possa estar enraizado na noção de ancestralidade comum, notase, ainda, que a criação de fronteiras entre 0 " $E u^{\prime}$ e 0 "Outro" parece ser um importante aspecto de construção e reforço de identidade étnica (Lesch, 1998, p.5). Enfim, por meio de inúmeras referências (ancestralidade comum, contato com o diferente, marcas e sinais distintivos, tais como vestimentas, cor da pele e nomes próprios etc.), a autoidantificasão revela-se 0 critério crucial para determinação da identidade (D eng, 1996).

É importante observar de que maneira fatores exógenos como a chegada do sistema de colonização contribuem para a formação das identidades em geral, e no caso do Sudão em particular, examinando em que grau o colonialismo distorceu os modos de autoidentificação e produziu as identidades dos subjugados. Um mecanismo artificioso do regime colonial na África era, conforme argumentação de Terence Ranger e Eric Hobsbawm (2002), a "invenção de tradições", que mostra primeiro como a construção de rituais imperiais (centrados no culto da monarquia britânica, no caso do Sudão) forneceram modelos de subserviência dentro dos quais era possível atrair africanos (Sharkey, 2003, p.97). Os novos rituais cívicos, construções arquitetônicas e monumentos nacionais inventados pelo colonizador rearticulam solidariedades simbólicas, redesenham a mitologia do passado - aprofundando, entre os diferentes grupos, a disputa pela história - e tem como produto o aprisionamento dos povos aos modos de pensar dos dominantes.

Tal jugo provoca um efeito psicossocial curioso em grande parte da população dominada, qual seja, a tendência ao comportamento colonizador dos colonizados. Isto é, os povos submetidos à autoridade estrangeira - e que, portanto, experienciam cdeivamenteos dramas de ser colonizado - transvertem suas ações políticas para afirmar sua superioridade sobre outros povos; o fenômeno pode ser verificado nas atitudes egípcias (povo dominado pelos britânicos) sobre o Sudão, e do norte do Sudão (dominado pelos britânicos e egípcios) em relação ao sul do Sudão. A interessante discussão, que geraria desdobramentos teóricos extraordinários (contemplando diversas áreas de conhecimento), será abordada aqui de forma bastante sucinta, com base no texto de Eve Troutt Powell (2003) e de alguns autores pós-coloniais.

Conforme destaca Eric Hobsbawm (1992), a partir da "era dos Impérios", a resposta dos povos dependentes foi um esforço de incorporar os modelos do ocidente; 
criando uma virtual e textual realidade do "oriente", os europeus engendraram o processo do imperialismo a partir da construção da diferença cultural ${ }^{31}$. Grande parte dos teóricos do "orientalismo", pensamento desenvolvido na década de 1970, fundamenta-se nas obras dos anos 1950 e 1960 de Franz Fanon, Albert Memmi e Jean-Paul Sartre, primeiros a retratar as vidas dos sujeitos ao colonialismo europeu, e que criam um cânone para os estudos póscoloniais (Powell, 2003). O processo de colonização e ocidentalização - por meio de aspectos de reorganização da sociedade como, por exemplo, o reordenamento militar, classificação da população em censos, alargamento das ruas (agora em linhas ortogonais), modelos arquitetônicos para escolas e prisões - introduz novos elementos na realidade dos dominados, seja pela produção da "auto-colonização do colonizado" (Mitchell, 1990. Apud Powell), seja pela reprodução de tendências colonizadoras. No caso do Egito (foco do livro de Troutt Powell), por exemplo, o impacto do imperialismo define-se no estabelecimento de relações triangulares - a saber, entre Londres, Cairo e Cartum - que tenta criar seu próprio império no Sudão, ao longo de todo o século XIX e na primeira metade do XX, por meio de uma política externa ao mesmo tempo anti-colonialista e expansionista, apresentando-se como sujeito e objeto do sistema de colonização.

Ao identificar as tendências sub-imperialistas do Egito, podese aplicar a mesma fórmula para as ambições políticas do norte do Sudão que, no conjunto, refletem a situação de uma região dominada que, ao longo da história (mas, em epecial, depois do estabelecimento ocidental), tenta demonstrar sua superioridade sobre o sul do Sudão, por meio da conquista política efetiva e da assimilação cultural. Assim, os árabes do norte, utilizando-se dos mesmos processos ocidentais, forjam uma identidade nacional sudanesa inventando condições sócio-culturais propicias - de modo que pudessem "coloniza" a parte meridional do país. Assim, árabes e africanos existem como invenções não apenas no discurso colonial, mas como invenções no contexto sudanês (Idris, 2005, p.102).

\section{2 - 0 Processo de Arabização}

Para compreender o processo de arabização (bem como de islamização) intimamente relacionado a projetos políticos do norte, é imprtante identificar a constituição dos povos árabes do norte na história do Sudão e suas implicações. Vale apontar que a configuração das identidades no Sudão tem sido o resultado dos laços históricos com o mundo externo (Deng, 1996). A partir das vagas árabes, que chegaram ao Sudão no século VI, ocorre paulatinamente uma alteração nas características físicas dos

31 Ver a obra do palestino Edward Said, Oriettalismo 
habitantes locais, como decorrência das miscigenações; assim, as resultantes raciais dos povos do norte do Sudão mostram-se semelhantes às dos povos da Etiópia, Eritréia, Somália, Níger e Mali, só que estes se identificam como aficanos, enquanto os nortistas do Sudão qualificam-se como árabes $\mathrm{O}$ fator raça na região setentrional predomina em favor da ancestralidade africana, tomando, deste modo, dúbia a identificação com os árabes (Ilid, 1996). É curioso notar a marginalização dos árabes do norte do Sudão promovida pelos árabes de outras regiões (partcularmente do Oriente Médio): os últimos não raro discriminam os sudaneses árabes por conta da pele mais escura e pelos padrões culturais distintos, sendo chamados pejorativamente de Abid que significa "escravo" (Lesch, 1998) ${ }^{32}$.

Contudo, no estabelecimento, em 1898, do regime anglo-egípcio, segundo Heather Sharkey (2008), não havia a auto-identificação árabe sudanesa entre as elites islâmicas das regiões ribeirinhas (embora, como dito, houvesse a percepção do ser unicamente árabe). Na visão dos muçulmanos (do alto-escalão, principalmente), ser sudanês significava ser nego, em função da expressão que designava as terras que se estendiam do Senegal à Etiópia como Bilad al-Sudan ("terra dos negros"); e como ser negro significava ter baixo status social (devido ao fenômeno do escravismo), nenhum árabe desejava se sudanês. Ainda, conforme indica a autora, as atoridades coloniais britânicas preservaram muito da estratificação árabes-negros, mesmo com a imposição para o fim do tráfico, em $1899^{33}$. No que diz respeito ao adjetivo sudari - que tinha adquirido uma conotação de servilidade -, deve-se mencionar que, após 1924, a Inglaterra passou a utilizar para todos os povos do território do Condomínio, com a função de distingui-los dos egípcios. Desta forma, a partir desta época, o termo acaba por se transformar em uma forte auto-referência nacionalista, no sentido de se construírem epítetos nacionais, por meio de nomes que marcassem sua identidade (Sharkey, 2003, pp.18-31), o que indica o caráter de fluxo da palavra "sudanês". Com a apropriação "enobrecida" do termo pelas elites nacionalistas árabes do norte (agora, auto-proclamados árabessudaneses), a forma de abordagem aos habitantes do sul era expressa pela palavra abid ("escravo") $)^{34}$.

Diante desta nova conjuntura, inicia-se gradualmente o projeto de arabização (tarib), que vai ser interrompido com a aplicação da Sathem Pdigye, logo, retomado com grande intensidade ao longo da formağo do Estado-nação e no pósindependência -

32 O utro fator para a discriminação provém da ortodoxia religiosa islâmica que, por vezes, rejeita aspectos de sincretismo existentes em algumas regiões do Sudão.

${ }_{33}$ Como foi visto os oficiais ingleses respeitaram hierarquias locais e reforçaram-nas por meio de políticas educacionais.

${ }^{34} \mathrm{O}$ uso de abidpode ser comparado à utilização de nigger no contexto norte-americano, sempre dito em tom pejorativo. Os sudaneses do sul costumam responder à provocação com a frase "somos todos escravos de Deus!". 
transformando-se em política oficial na década de 1950. No Condomínio, a aabização ocorreu em dois caminhos: tanto dentre as comunidades de ex-escravos negros do sul, quanto dentre os não-árabes do próprio norte e oeste (neste caso, na província de Darfur), a partir de códigos de procedimento como, basicamente, o estabelecimento dos árabes naquelas regiões, casamentos interétnicos e assimilação lingüística (Sharkey, 2008) ${ }^{35}$. A política de arabização, como mencionado, endureceu na década de 1950, no caminho à independência, e mais energicamente em função dos motins de 1955 e do início da guerra civil, com 0 intuito de resguardar a herança colonial de território unificado e a proporcionar a unidade nacional.

A ideologia arabista estimulou, em contrapartida, a formação de uma ideologia africanista opositora, que, manifestando-se como contra-identidade, enfatiza as conexões com as culturas plurais do continente africano, bem como com as ligações lingüísticas - em detrimento de categorias singulares árabes (llid, 2008). Para D unstan Wai (1980), os povos do sul são racialmente ligados à África tropical e identificam-se culturalmente com 0 africanismo. Com essas duas balizas etno-culturais no centro dos conflitos de identidades, um artifício válido na luta pda afirmação grupal em âmbito nacional diz respeito à reapropriação da história do Sudão: a politização da históra, colocada em disputa, manifesta-se por meio das imagens contestadas pelos diferentes grupos de elite, tanto do norte, quanto do sul (Lesch, 1998).

É imprescindível relembrar, no entanto, que o conflito de identidades, a partir de 1955, é traduzido em manifestações concretas de violência física que exibem consequiências monumentais na vida de milhares de sudaneses. $\mathrm{O}$ historiador sudanês sulista Amir Idris (2005) questiona como todos os sudaneses poderiam se libertar das algemas impostas por um discurso construído sob representações binárias - essencializadas pela experiência colonial - e que fundamentam ações mútuas de brutalidade, a fim de expurgar 0 florescimento de idéias racistas. No conjunto, deve-se pontuar que o projeto de arabização (e sua contrapartida africanista) no contexto de construção do Estado-nação recria noções de superioridade étnica e cultural, deturpando percepções sobre o "outro" e que, associadas a mecanismos que impedem o acesso efetivo dos sulistas às instituições nacionais, desembocam nos confrontos armados entre as regiões.

35 As comunidades não-árabes do norte, convertidas ao Islã, sentem-se, contudo, órfãs do arabismo, o que, posteriormente, dá ensejo a um movimento de aproximação com a região meridional, em virtude da percepção de suas similaridades - o que contradiz a simples dicotomia norte-sul (D eng, 1996). 


\section{Bibliografia}

1. ARMSTRO NG , John. Nations before Nationalism Chapel Hill: University of North Carolina Press, 1982.

2. BARTH, Fredrick (ar). Ethnic Group and Bandaries The Soial Organization of Culture Difference London: Allen \& Unwin, 1969.

3. CO LLINS, Robert O. Shadous in the Grass Bitain in the Sathem Sudan, 19181956. New York: Yale University Press, 1983.

4. CO QUERY-VIDROVITCH, Catherine.; MO NIOT , H. Africa Negra: de 1800 a Nuestros Días. Barcelona: Editorial Labor, 1976.

5. D ALY, Martin W. Empire on the Nile The AngoEgptian Sudan, 1898-1934 Cambridge: Cambridge University Press, 2005.

6. DALY, Martin W. Impeial Sudan: the AngoEgptian Condominium 1934-1956. Cambridge: Cambridge University Press, 2003.

7. D ALY, Martin W., HO LT, Peter M. A Histary of the Sudan: From the Coming of Islam to the Preset Day. London: Longman, 2000.

8. DENG , Francis M. War of Visions: Conflids of Idantities in theSudan Washington: Brookings Institution Press, 1995.

9. EL-AFFENDI. Abdelwahab. "Discovering the South: Sudanese Dilemmas for Islam in Africa". AfricanAffairs 89:356 (1990), pp. 371-89.

10. FERKISS, Victor C. África: umContinenteà Proura deseu Destima Rio de Janeiro: Edições GRD, 1967.

11. GATKUOTH, James Gabor. "Ethnicity and Nationalism in the Sudan: A Challenge to the Churches". TheEammical Review Apr., 1995.

12. G O ULD NER, Alvin W. "Stalinism: A Study of Internal Colonialism". Tdos 34, 1978.

13. HARG REAVES, John D. DeedorizationinAfica Harlow: Longman, 1988.

14. HASABU, Abu; MAJID , Afaf Abdel. TheFactional Conflid in theSudanese National Movenent, 1918-1948. Khartoum: Graduate College, University of Khartoum, 1985.

15. HO BSBAWM, Eric J. A Era dos Impéios Rio de Janeiro: Editora Paz e Terra, 1992.

16. HO BSBAWM, Eric; RANGER, Terence. A Invenção das Tradiçóes Rio de Janeiro: Paz e Terra, 2002.

17. HOWELL, John, "Politics in the Southem Sudan”. AfricanAffairs Vol. 72, No. 287 (Apr., 1973), pp. 163-178.

18. HUTCHINSO N, John; SMITH, Anthony D (org.). Ethriaty. Oxford: Oxford University Press, 1996.

19. ID RIS, Amir. Conflid andPditics of IdantityinSudan New Y ork: Palgrave Macmillan, 2005.

20. JOHNSON, D ouglas H. "Tribal boundaries and border wars: Nuer-Dinka relations in the Sobat and Zaraf Valleys, 1890-1976". Jaumal of AfricanHistary, 23, 1982.

21. JOHNSO N, D ouglas Hamilton. TheRoot Causes of Sudan's Civil Wars Bloomington: Indiana University Press, 2005.

22. KI-ZERBO , Joseph. Históia daÁficica Negra Lisboa: Europa-América, 1991, vol. II.

23. LESCH, Ann Mosely. The SudanContested National Idantities Bloomington: Indiana University Press, 1998.

24. MAG HO UB, Mohamed A hmed. Demmaay on Trial: Refletions on Arab and Afican Pditics London: Andre Deutsch, 1974.

25. MEY EROWITZ, Eva L. R. "The Southern Sudan Today". AfricanAffairs, Vol. 62, No. 248 (Jul., 1963), pp. 274-279.

26. MITCHELL, Timothy. CdonisingEgyt. Cambridge: Cambridge University Press, 1990.

27. O'FAHEY, R. S. "Islam and Ethnicity in the Sudan". Jaumal of RdigininAfrica, Vol. 26 (3), pp. 258-267, Aug., 1996.

28. POWELL, Eve M. Troutt. A Different Shade of Cdonialism Egypt, Great Britain and theMastery of theSudan Berkeley: University of California Press, 2003. 
29. RAHIM, Muddathir Abdel. "Arabism, Africanism, and Self-Identification in the Sudan". TheJaumal of Modem Afiican Studies 8 (2): 233-249, 1970.

30. RAHIM, Muddathir Abdel. Imperialism\& Nationalismin theSudan: A Surdyin Constitutional \& Pditical Dedeqment, 1899-1956. K hartoum: K hartoum University Press, 1987.

31. RUAY, D eng D. Akol. The Pditics of Two Sudans. The Sath and the Nath, 1821 - 1969. Uppsala: Nordic African Institute, 1994.

32. SAID , E dward W. Orientalismo O OrientecomoInveņãodbOadente São Paulo: Companhia das Letras, 1996.

33. SARKESIAN, Sam C. "The Southern Sudan: A Reassessment". African Studies Review16(1): 1-22, 1973.

34. SHARKEY, Heather. "Arab Identity and Ideology in Sudan: The Politics of Language, Ethnicity, and Race". AfricanAffairs 0/ 0, 1-23, 2008.

35. SHARKEY, Heather. Living with Cdonialism Nationalism and Culture in the AngoEgptian Sudan Berkeley: University of California Press, 2003.

36. STAVENHAGEN, Rodolfo. Ethric Conflids and the Nation-State Hampshire: Macmillian Press, 1996.

37. VOLL, John O. Sudan State and Saidy in Crisis Bloomington: Indiana University Press, 1991.

38. WAI, D unstan M. "Pax Britannica and the Southern Sudan: The View from the Theatre". AfricanAffairs 79(316): 375-395, 1980.

39. WAI, D unstan. The AfricanArab Conflid in the Sudan New York: Holmes \& Meier Publishers, 1981.

40. WARBURG, Gabriel. "The Condominium Revisited: The Anglo-Egyptian Sudan 1934 1956: A Review Article". Bullein of theSchod of Orietal and African Studies, University of London 56(1): 1-12, 1993.

41. WOODWARD, Peter. "Nationalism and Opposition in Sudan". African Affairs 80(320): 379-388, 1981.

42. WOOD WARD, Peter. Condaminium and Sudanæe Nationalism Totowa: Barnes and Noble Books, 1980. 